\title{
Comparison and predesign cost assessment of ozonation, membrane filtration and activated carbon for the treatment of recalcitrant organics, a conceptual study
}

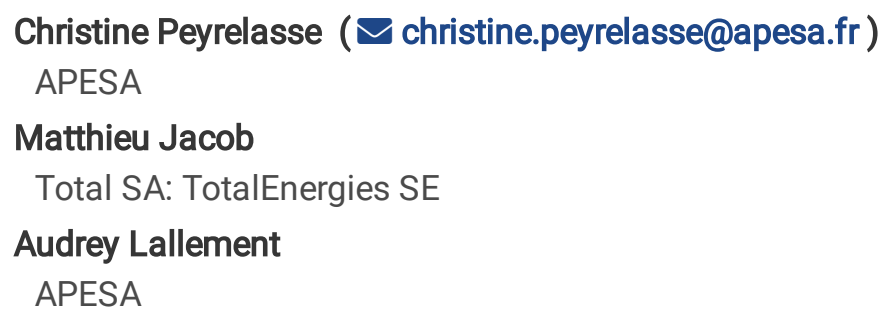

\section{Research Article}

Keywords: Ozone treatment, granular activated carbon, membrane filtration, wastewater treatment, organic pollutant

Posted Date: August 19th, 2021

DOI: https://doi.org/10.21203/rs.3.rs-802348/v1

License: @ (i) This work is licensed under a Creative Commons Attribution 4.0 International License. Read Full License 


\section{Abstract}

The presence of micropollutants in the environment is today of major concern. These pollutants could have long-term impacts on the environment and on population health. Biological treatment of wastewater is generally insufficient to allow their complete elimination. The establishment of efficient treatments is then needed to degrade the refractory organic matter. Activated carbon adsorption, membrane filtration and oxidation processes are common suitable solutions. All of them have advantages and are effective to treat wastewaters but drawbacks are well known such as waste production, energy consumption or by-products formation. This study aims at defining a strategy to choose the best option according to the nature of the wastewater and the treatment objectives. A methodology was designed for the rating of theses processes to choose the best strategy regarding environmental, technical and economic criteria. A simulation of three wastewater treatment scenarios was carried out to compare the costs of ozonation, adsorption and reverse osmosis. According to the result obtained, a decision tree is proposed to define the best option for a tertiary treatment to reach reuse or discharge objectives.

\section{Highlights}

- Micropollutants are of major concern on surface water quality and population health.

- Tertiary treatments remove recalcitrant organics depending on wastewater nature and objectives.

- An optimization of the processes is needed to limit environmental issues.

\section{Introduction}

The presence of micropollutants in today's environment is of major concern. Research has permit to create new chemical compounds for medicine, chemistry, cosmetics and agriculture (phytosanitary) uses. These compounds belong to the family of surfactants, flame retardants, pharmaceuticals, cosmetics, petrol additives, biocides, pesticides and all of their degradation products. The fate of these new compounds in the environment need to be measured as their behavior, their fate and their (eco)toxicological effects are not very well known (Norman, 2018).

They can have toxic effects (carcinogenic, mutagenic or reprotoxic) or even interfere with the hormonal system of living beings (endocrine disruptors). They could also have health and environmental effects in short or long terms. Furthermore, the potential risk of a "cocktail" effect due to a mixt of these compounds must be considered. Over 1,000 substances have been referenced as emerging environmental substances (Norman, 2019). Since 2000, the European Directive 2000/60/EC (European commission, 2000) sets the reduction target of hazardous substance emission in water. A list of substances or group of substances concerned by the emission reduction (defined as priority substances) or elimination (considered as hazardous priority substances) by 2021 has been defined. The first list, published in 2001, included 33 priority substances (metals, pesticides, hydrocarbons) and evolved with the Directive 2008/105/EC (2008/105/EC, 2008) amended by the Directive 2013/39/EC (2013/39/EU, 2013).

The Industrial Emissions Directive (IED), adopted on 24 November 2010, defines an integrated approach to prevent and reduce the industrial emissions (integrated pollution prevention and control) (European Commission, 2010). The IED provides emission thresholds associated with the performant technic available (BAT-AELs) presented in the BREF documents. BAT-AELs exist for direct emissions of Total Organic Carbon (TOC) and Chemical Oxygen Demand (COD) for a receiving water. For COD, the BAT-AELs threshold for emissions are between 30 to $300 \mathrm{mg} \mathrm{L}^{-1}$ (Brinkmann et al., 2016; Chronopoulos et al., 2019; Pinasseau et al., 2018).

With the tightening of regulatory constraints, releases of some pollutants are decreasing, such as pesticides, however other substance releases are increasing, like pharmaceutical substances (Metz \& Ingold, 2014). The organic pollutants including emerging pollutants in urban or industrial effluents are not completely biodegradable and a part of these compounds are refractory to biological treatments. Consequently, pollutants are measured at the output of activated sludge treatments (Baalbaki et al., 2017; Coquery et al., 2008; Du et al., 2014; Margot et al., 2013; Ruel et al., 2011), which are the most conventional treatment for urban wastewaters. The main mechanisms involved in the elimination of micropollutants in

Page 2/19 
biological treatments are mainly biodegradation but also sorption onto sludge, air stripping and phototransformation (Gusmaroli et al., 2020). The implementation of tertiary treatments may be required to allow the elimination of these refractory pollutants and to increase the water quality discharged to surface waters.

Adsorption on activated carbon, Reverse Osmosis (RO) and oxidation are the common treatment solutions implemented as tertiary treatment. Activated carbon is widely employed to remove organic compounds in industrial or drinking waters. This treatment presents various advantages: easily to implement and operate, no chemical needs and no generation of by-products. However, the replacement of the spent activated carbon is necessary and the cost involved limits its use on low COD concentration effluents. RO presents also very high treatment performances but requires efficient pre-treatment and high opertational costs due to energy consumption, elimination of the retained pollutants (retentate) and a qualified staff to operate and control the process. Only the oxidation processes make it possible to really degrade polluants but formation of unknown and potential toxic by-products can occur due to partial oxidation of the compouds (Hamdi El Najjar et al., 2014; Wu et al., 2019).

Studies comparing the costs of tertiary treatments to reduce the discharge of micropollutants are generaly available for urban wastewater treatment plants (Bui et al., 2016; Wahlberg et al., 2010). Few works exist on the field of tertiary treatments employed for industrial wastewaters. This study aims to achieve a comparison and a predesign cost assessment of ozonation, reverse osmosis and activated carbon for the treatment of an industrial effluent with a COD concentration higher than values commonly found in urban discharges. Attempts have been made to estimate the capital and annual operating and maintenance cost (O\&M cost) for a 2,000 $\mathrm{m}^{3} \mathrm{~d}^{-1}$ capacity treatment plant with a COD concentration of $500 \mathrm{mg} \mathrm{L}^{-1}$. Secondly, a multi-criteria approach is proposed to compare the performance of the processes. Finally, a decision tree is designed to select the most appropriate treatment for the elimination of dissolved organics.

\section{Predesign Cost Assessment}

\subsection{Costs of the tertiary treatments}

\subsubsection{Ozonation cost}

Ozone generators are supplied with air for low capacities (maximum of $75 \mathrm{kgO}_{3} \mathrm{~h}^{-1}$ per ozone generator) and with oxygen for larger needs ( $200 \mathrm{kgO}_{3} \mathrm{~h}^{-1}$ maximum by ozonator) (Baig and Mouchet 2017). Ozone generators operating with air have higher energy consumption than those operating with oxygen, 13 to $20 \mathrm{kWh} \mathrm{kg}^{-1} \mathrm{O}_{3}$ compared to 7 to $13 \mathrm{kWh} \mathrm{kg}^{-1} \mathrm{O}_{3}$ (Baig \& Mouchet, 2017). The oxygen consumption of ozone generators supplied with oxygen are around $8.3 \mathrm{kgO}_{2} \mathrm{~kg}^{-1} \mathrm{O}_{3}$ (Xylem, 2017) with an oxygen cost estimated at $0.1 € \mathrm{~kg}^{-1}$ (besnault et al., 2015).

The first cost of investment is the ozone generators. RECORD (2006) established this cost (excluding engineering) between 150 $€ \mathrm{~g}^{-1} \mathrm{O}_{3} \mathrm{~h}$ and $30 € \mathrm{~g}^{-1} \mathrm{O}_{3} \mathrm{~h}$ for the highest capacities, greater than $10 \mathrm{~kg} \mathrm{~h}^{-1}$ (RECORD, 2006). Similarly, Mendret et al. (2019) considered a ratio of $100 \$ \mathrm{~g}^{-1} \mathrm{O}_{3} \mathrm{~h}$ for a capacity of $1.15 \mathrm{kgO}_{3} \mathrm{~h}^{-1}$, based on feedback from suppliers and manufacturers of ozone generators, and Landry Carter (2017) gave a ratio of $54 \$ \mathrm{~g}^{-1} \mathrm{O}_{3} \mathrm{~h}$ corresponding to an investment cost (Ex-works) of $\$$ $2,500,000$ for an ozone generator of $46 \mathrm{kgO}_{3} \mathrm{~h}^{-1}$. This cost, including the injection, agitation and residual ozone destroyer system, was communicated by the company Primozone (Sweden) (Landry Carter, 2017).

\subsubsection{Granular Activated Carbon (GAC) cost}

GAC is implemented in a filter bed for the adsorption of organics on granular carbon. Process energy requirements are low for GAC and include both supply and backwash pumping (Hansen et al., 1979). The pollutants are eliminated by adsorption due to their affinity with the activated carbon and its high specific surface area of this adsorbent. The consumption of activated 
carbon can be first estimated from the COD load treated, typically in the range of 250 to $500 \mathrm{~g} \mathrm{COD} \mathrm{kg}^{-1} \mathrm{AC}$ or higher (Truc, 2007). In first approach, a consumption of 250 to $300 \mathrm{~g} \mathrm{COD} \mathrm{kg}^{-1} \mathrm{AC}$ is generally considered. Performances of this treatment are dependant of the organics compounds to be adsorbed and in particular the polarity, molecular weight, solubility and concentration. This can be evaluated in laboratory by adsorption isotherms. After the saturation, activated carbon must be replaced and reactivated in high temperature ovens. In France, the reactivation of coal is done in specialized centers, it is too expensive to be carried out on user sites (Bui et al., 2016).

The reactivation yield is dependent on the type of carbon and the nature of the molecule adsorbed. For charcoal made from softwood (pine) this yield is relatively low (70-90\%), while for charcoal made from coconut it can reach $98 \%$ (information obtained from Chemviron 2019). Treatment of the spent GAC in a reactivation center will require a prior acceptance certificate with limits to be respected for certain parameters such as sulfur, chlorine and fluorine.

The cost of GAC is generally between 1 and $4 € \mathrm{~kg}^{-1}$ and the cost for the reactivation is $0.6-0.7 € \mathrm{~kg}^{-1}$ (excluding transport). The reactivation cost is slightly higher than the elimination cost $\left(0.4-0.5 € \mathrm{~kg}^{-1}\right)$, but leads to savings on the purchase of new GAC until it cannot be reactivated. Activated carbon treatment should not be used when treated fluxes have too high COD due to the costs associated with the carbon reprocessing. The investment costs were identified and estimated by the company IRH as part of a study carried out for the Rhône Mediterranean Corsica Water Agency. This preliminary design approach is exclusive of taxes and fees and doesn't include supply (cost and mankind), the contracting authority staff and the project management mission (IRH, 2010). The investment costs are very dependent on the capacity and are here established at $50 € \mathrm{~m}^{-3} \mathrm{~d}$ and $625 €$ $\mathrm{m}^{-3} \mathrm{~d}$ for the highest and lowest capacities respectively $\left(60\right.$ and $\left.1 \mathrm{~m}^{3} \mathrm{~h}^{-1}\right)$. Significantly higher costs have been estimated by Guo et al. (2014): $350 € \mathrm{~m}^{-3} \mathrm{~d}$ and $960 € \mathrm{~m}^{-3} \mathrm{~d}$ for the same highest and lowest capacities. For them, the investment cost covers the process, initial charge of activated carbon, piping, control and instrumentation and is linked to the flow quantity treated:

$\log ($ Capital cost $(\$))=0.722 \times \log \left(\right.$ flow rate $\left.\left(\mathrm{m}^{3} \mathrm{~d}^{-1}\right)^{1.023}+3.443\right) \quad$ Guo et al. $(2014)$

This equation was mainly defined using a simulation tool created by the Water Research Foundation and the USEPA.

Altogether, the investment costs depend on the flow treated and on its composition influencing the nature of the material used, the kinetic of filtration end the number of filters used.

\subsubsection{Membrane filtration cost assessment}

Reverse osmosis and Nanofiltration (NF) are implemented for water reuse or very strict constraints on discharges (very low threshold or low water flow rate authorized for discharge). They require more efficient pre-treatment than adsorption and ozonation. Energy consumption is higher and the elimination of retentate (10 to $30 \%$ of the initial volume of water treated) remains problematic impacting the operating fees. NF and RO investment costs, identified by the company IRH, are estimated near 1,500-1,750€ $\mathrm{m}^{-3} \mathrm{~d}$ (for units treating 200-300 $\mathrm{m}^{3} \mathrm{~d}^{-1}$ ) and 7,500 $€ \mathrm{~m}^{-3} \mathrm{~d}$ (for a capacity lower than $10 \mathrm{~m}^{3} \mathrm{~d}^{-1}$ ). In addition, an additional cost of 25 to $30 \%$ must be taken into account for the assembly, commissioning, etc. (IRH, 2010). In another study, Plumlee et al. (2014) have proposed an equation for capital cost estimation linking the overall investment (process and auxiliary costs) to RO and NF:

Capital cost $\left(\$ M M G D^{-1}\right)=7.14 \times$ flow rate $(M G D)^{-0.22} \quad$ Plumlee et al. (2014)

Where, capital cost is in \$M MGD ${ }^{-1}$ and the flow rate is in MGD (Millions of Gallons per Day) with 1 US MGD $=3,785 \mathrm{~m}^{3} \mathrm{~d}^{-}$

1 . This equation can be used for flows higher than $1 \mathrm{MGD}$.

The overall capital cost was thus estimated at $1,500 € \mathrm{~m}^{-3} \mathrm{~d}$ for a unit treating $3,800 \mathrm{~m}^{3} \mathrm{~d}^{-1}$. This cost could be lower for the treatment of slightly polluted unsalted water. 
For our simulations, the equation of Plumlee et al. (2014) will be used for a simulated unit with a flow at 0.5 MGD (assumption supported by the supporting information of (Plumlee et al., 2014) publication).

\subsection{Cost assessment of the different wastewater treatment scenarios used for the comparison of costs}

Studies comparing the costs of tertiary treatments are generally carried out for urban wastewater treatment plant applications (Bui et al., 2016; Choubert, 2018; Wahlberg et al., 2010). Only few works exist on these tertiary treatments on industrial wastewaters. The economic considerations drive the selection of the process implementation. Here, a simulation of different scenarios for is proposed to treat a conceptual effluent with a COD concentration at $500 \mathrm{mg} \mathrm{L}^{-1}$ (higher than urban waste concentration). A comparison of the 3 different treatment processes (ozonation, adsorption and membrane filtration) is carried out on a cost basis. Treatment channels considered are presented in Fig. 1. The channel with membrane filtration (ultrafiltration / reverse osmosis) is considered to study a scenario with water reuse.

In the different scenarios tested, the three post processes are described as follow:

- Membrane channels: wastewater is first filtered by ultrafiltration and reserve osmosis and retentate is post-treated by ozonation. Two scenarios are proposed here with permeate directly discharged (Channel 1) or reused (Channel 1 bis).

- Activated carbon channels: wastewater is treated by AC post-treatment, the obtained water can directly be discharged. Two scenarios here are considered using either reactivated AC (Channel 2) or new AC (Channel 2 bis).

- Finally, wastewater can be processed directly by ozonation treatment allowing direct discharge.

\subsubsection{Hypothesis used in the simulation}

General assumptions used for simulation are:

- A flow rate at $2000 \mathrm{~m}^{3} \mathrm{~d}^{-1}, 24 \mathrm{~h} / 24,365$ days per year;

- An electricity cost at $0.1 € \mathrm{kWh}^{-1}$;

- A staff cost fixed at $50 € \mathrm{~h}^{-1}$.

The capital cost is amortized over 20 years (n) (Besnault et al., 2014) considering an interest rate ( $r$ ) of $4.5 \% \mathrm{y}^{-1}$ (Margot et al., 2013). The amortized capital cost (A) is given by the following equation (Mahamuni \& Adewuyi, 2010):

$$
A=\frac{\text { Total capital } \times \mathrm{r}}{1-\left(\frac{1}{1+\mathrm{r}}\right)^{\mathrm{n}}}
$$

Specific hypotheses of each scenario are listed in Table 1.

Table 1. Assumptions for cost estimation (APESA, RECORD 2020). 


\begin{tabular}{|c|c|c|c|c|c|c|}
\hline \multirow[t]{2}{*}{ Item } & \multicolumn{3}{|c|}{$\mathrm{UF}+\mathrm{RO}+\mathrm{O}_{3}$, Channel 1 and 1 bis } & \multicolumn{2}{|c|}{ GAC, Channel 2 and 2 bis } & \multirow{2}{*}{$\begin{array}{l}\mathrm{O}_{3}, \text { Channel } 3 \\
\mathrm{O}_{3}\end{array}$} \\
\hline & UF & RO & $\mathrm{O}_{3}$ & $\begin{array}{l}\text { GAC } \\
\text { Elimination }\end{array}$ & $\begin{array}{l}\text { GAC } \\
\text { Reactivation }\end{array}$ & \\
\hline \multirow[t]{2}{*}{ Performances } & $10 \%$ COD reduction & $\begin{array}{l}95 \% \text { COD } \\
\text { reduction }\end{array}$ & $\begin{array}{l}>90 \% \text { COD } \\
\text { reduction }\end{array}$ & \multirow{2}{*}{\multicolumn{2}{|c|}{$300 \mathrm{gCOD} \mathrm{kg}^{-1} \mathrm{GAC}$}} & $\begin{array}{l}>90 \% \text { COD } \\
\text { reduction }\end{array}$ \\
\hline & $95 \%$ recovery ratio & $\begin{array}{l}80 \% \text { recovery } \\
\text { ratio }^{(\mathrm{f})}\end{array}$ & $\begin{array}{l}90 \% \mathrm{O}_{3} \text { for } \\
\text { transfer } \\
\text { efficiency }{ }^{(l)}\end{array}$ & & & $\begin{array}{l}90 \% \mathrm{O}_{3} \text { for } \\
\text { transfer } \\
\text { efficiency }\end{array}$ \\
\hline Maintenance & $\begin{array}{l}0.026 \$ \mathrm{~m}^{-3} \mathrm{x} \\
\text { conversion rate } € / \$ \\
\text { (a) }\end{array}$ & $\begin{array}{l}3 \% \text { capital cost } \\
y^{-1}(g)\end{array}$ & $\begin{array}{l}1.5 \% \text { of the } \\
\text { process } \\
\text { capital cost } y^{-} \\
1 \text { for the } \\
\text { annual part } \\
\text { replacement } \\
\text { cost }(\mathrm{m})\end{array}$ & \multicolumn{2}{|c|}{$\begin{array}{l}1.5 \% \text { of the process capital } \\
\text { cost } y^{-1}\end{array}$} & $\begin{array}{l}1.5 \% \text { of the } \\
\text { process } \\
\text { capital cost } y^{-} \\
1 \text { for the } \\
\text { replacement } \\
\text { (m) }\end{array}$ \\
\hline $\begin{array}{l}\text { Operating } \\
\text { and } \\
\text { maintenance } \\
\text { staff }\end{array}$ & $21 \mathrm{~h}$ month $^{-1}(\mathrm{~b})$ & $0.2 € \mathrm{~m}^{-3}(\mathrm{~h})$ & $\begin{array}{l}150 \mathrm{~h} \mathrm{month}^{-} \\
1(\mathrm{n})\end{array}$ & \multicolumn{2}{|c|}{$22 \mathrm{~h} \mathrm{month}^{-1}(\mathrm{t})$} & $\begin{array}{l}170 \text { h month }^{-} \\
1(\mathrm{n})\end{array}$ \\
\hline \multirow[t]{4}{*}{$\begin{array}{l}\text { Consumables } \\
\text { (chemicals, } \\
\text { GAC, } \\
\text { membrane) }\end{array}$} & \multirow{4}{*}{$\begin{array}{l}0.025 \$ \mathrm{~m}^{-3} \mathrm{x} \\
\text { conversion rate } \\
€ / \$ \text { for membrane } \\
\text { replacement and } 2 \% \\
\text { of capital cost } \mathrm{y}^{-1} \\
\text { for the cleaning } \\
\text { agents }(\mathrm{a}, \mathrm{c})\end{array}$} & $\begin{array}{l}0.1 \$ \mathrm{~m}^{-3} \text { for } \\
\text { membrane } \\
\text { replacement and }\end{array}$ & $\begin{array}{l}2.5 \mathrm{gO}_{3} \mathrm{~g}^{-1} \\
\operatorname{COD}(\mathrm{o})\end{array}$ & \multirow{4}{*}{$\begin{array}{l}2 € \mathrm{~kg}^{-1} \text { for } \\
\text { a new one } \\
\text { and } 0.45 € \\
\mathrm{~kg}^{-1} \text { for the } \\
\text { elimination }\end{array}$} & \multirow{4}{*}{$\begin{array}{l}0.7 € \mathrm{~kg}^{-1} \\
\text { with a } \\
\text { regeneration } \\
\text { efficiency of } \\
95 \% \text { and } 2 € \\
\mathrm{~kg}^{-1} \text { for a } \\
\text { new one }\end{array}$} & $\begin{array}{l}2.5 \mathrm{gO}_{3} \mathrm{~g}^{-} \\
{ }^{1} \mathrm{COD}{ }^{(\mathrm{o})}\end{array}$ \\
\hline & & $\begin{array}{l}0.1 \$ € \mathrm{~m}^{-3} \text { for } \\
\text { the cleaning } \\
\text { agents }{ }^{3} \mathrm{x} \\
\text { conversion rate }\end{array}$ & $\begin{array}{l}8.3 \mathrm{kgO}_{2} \mathrm{~kg}^{-} \\
{ }^{1} \mathrm{O}_{3}(\mathrm{p})\end{array}$ & & & $\begin{array}{l}8,3 \mathrm{kgO}_{2} \mathrm{~kg}^{-} \\
{ }^{1} \mathrm{O}_{3}(\mathrm{p})\end{array}$ \\
\hline & & $\$ / €(g, i)$ & $\begin{array}{l}0.1 € \mathrm{~kg}^{-1} \mathrm{O}_{2} \\
\text { (q) }\end{array}$ & & & $10 \mathrm{kWh} \mathrm{kg}^{-3} \mathrm{O}$ \\
\hline & & & & & & $\begin{array}{l}0,1 € \mathrm{~kg}^{-1} \mathrm{O}_{2} \\
\text { (q) }\end{array}$ \\
\hline $\begin{array}{l}\text { Electrical } \\
\text { consumption }\end{array}$ & $\begin{array}{l}0.3 \mathrm{kWh} \mathrm{m}^{-3} \\
\text { permeate }^{(\mathrm{d})}\end{array}$ & $\begin{array}{l}2.8 \mathrm{kWh} \mathrm{m}^{-3} \\
\text { permeate }\end{array}$ & $\begin{array}{l}10 \mathrm{kWh} \mathrm{kg}^{-} \\
{ }^{1} \mathrm{O}_{3}(\mathrm{r})\end{array}$ & \multicolumn{2}{|c|}{$0.019 \mathrm{kWh} \mathrm{m}^{-3}(\mathrm{u})$} & $\begin{array}{l}10 \mathrm{kWh} \mathrm{kg} \\
{ }^{1} \mathrm{O}_{3}(\mathrm{r})\end{array}$ \\
\hline Water saving & & \multicolumn{2}{|l|}{$1.45 € \mathrm{~m}^{-3}(\mathrm{k})$} & & & \\
\hline $\begin{array}{l}\text { Capital cost } \\
(€)\end{array}$ & $\begin{array}{l}\text { Conversion rate } € / \$ \\
\times \text { Flow rate }(\mathrm{MGD}) \times \\
3.57 \times \text { flow rate } \\
(\mathrm{MGD})^{-0.22} \times 10^{6}(\mathrm{e})\end{array}$ & $\begin{array}{l}\text { Conversion rate } \\
€ / \$ \times \text { Flow rate } \\
(M G D) \times 7.14 \times \\
\text { flow rate } \\
(M G D)^{-0.22} \times 10^{6} \\
\text { (e) }\end{array}$ & $\begin{array}{l}\text { Process (30€ } \\
\left.\mathrm{g}^{-1} \mathrm{O}_{3} \mathrm{~h}\right) \\
\text { + piping } \\
(30 \%)+\text { site } \\
\text { work }(10 \%)+ \\
\text { contractors } \\
(15 \%)+ \\
\text { engineering } \\
(15 \%)+ \\
\text { contingencies } \\
(20 \%) \text { (s) }\end{array}$ & \multicolumn{2}{|c|}{ 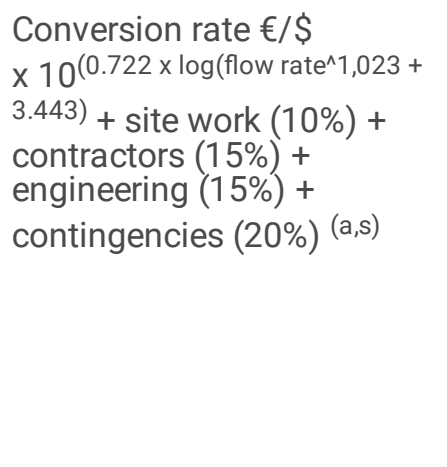 } & $\begin{array}{l}\text { Process (30 } € \\
\left.\mathrm{~g}^{-1} \mathrm{O}_{3} \mathrm{~h}\right) \\
\\
+ \text { piping } \\
(30 \%)+\text { site } \\
\text { work }(10 \%)+ \\
\text { contractors } \\
(15 \%)+ \\
\text { engineering } \\
(15 \%)+ \\
\text { contingencies } \\
(20 \%) \text { (s) }\end{array}$ \\
\hline
\end{tabular}

Reference used: (a) - (Guo et al., 2014); (b) - (Margot et al., 2011); (c) - (Andrade et al., 2015); (d) -(Guo et al., 2018) ; (e) (Plumlee et al., 2014); (f) - (Bick et al., 2012); (g) - (Shouman et al., 2015); (h) - (Koroneos et al., 2007); (i) - (Andrade et al., 2017); (j) - (Burn et al., 2015) ; (k) (Pedro-Monzonis et al., 2016); (l) - (Margot et al., 2013), (m) - (Mahamuni \& Adewuyi, 2010); (n) (Mundy et al., 2018) ; (o) - (de Franceschi, 2018); (p) - (Xylem, 2017); (q) - (besnault et al., 2015); (r) - (Baig \& Mouchet, 2017): (s) - (G.Melin (Ed.), 1999; Mahamuni \& Adewuyi, 2010); (t) - (Hansen et al., 1979) ; (u) - (Nijdam et al., 1999). 


\subsubsection{Results of cost calculation and discussion}

The O\&M (Operating and Maintenance cost) consists of maintenance, operating and maintenance staff, consumables and electrical costs. The consumables include the membrane replacement costs, the chemical costs and the GAC replacement with elimination or reactivation of the spent activated carbon. It also took in consideration the water saved (channel 1 bis). The annual O\&M and capital costs for all the scenarios have been calculated based on the aforementioned assumptions and are presented in Supplementary material.

The highest cost corresponds to the channel 1 which implements membrane filtration and ozonation for retentate treatment. This result confirms those of Wahlberg et al. (2010) and Choubert (2018) who showed that the reverse osmosis channels have the highest costs. The treatment cost can be revised downwards for the membrane filtration channel with water reuse. Considering that the water treated by RO is of very good quality and can be recycled, purchase of water and payment fees for withdrawals and rejections are saved. Indeed, the RO has the advantage of removing salts. Here an economy of $1.45 € \mathrm{~m}^{-3}$ of water recycled is considered (cost of surface water for industrial used (Pedro-Monzonis et al., 2016)). This cost can be higher or lower depending on the origin of water. Pedro-Monzonis et al. (2016), for example, considered for industrial water a cost of $0.18 € \mathrm{~m}^{-3}$ by employing groundwater. Thereby, RO with water saving can be a very interesting option depending on the regulatory of the sites and the price of water. When the activated carbon can be reactivated, the overall treatment cost is the lowest simulated. However, if GAC is eliminated and not reactivated, cost increases from $1.5 € \mathrm{~m}^{-3}$ to $4.2 € \mathrm{~m}^{-3}$ impacting the overall cost. In the case of ozonation, a cost of $3.6 € \mathrm{~m}^{-3}$ has been calculated.

This simulation provides a comparison of the costs for the different tertiary treatment plants and shows the impact of the various assumptions on the overall result. However, estimations are carried out on the basis of average treatment performance assumed for a fictitious effluent and not from available data for a real effluent. The treatment rates necessary for ozonation, the consumption of activated carbon as well as the performances of membrane filtration are specific to each effluent and could differ significantly from the assumptions made for this conceptual study.

\section{Comparison Of Processes And Strategy Of Treatment 3.1 Environmental impact}

A comparison of the environmental impacts of ozonation, GAC and membrane filtration has been carried out by Li et al. (2019). The tertiary treatments studied are positioned at the outlet of urban treatment plants. The toxicological impact linked to the rejection of hazardous products and pharmaceutical residues is included in the assessment. This study showed that the scenario with reverse osmosis (RO) has the highest environmental impact due to the consumption of energy and material during operation. Bayer et al. (2005) performed a Life Cycle Analysis (LCA) to compare the impact of a new GAC with that of a reactivated GAC. The results showed that (thermal) reactivation allows to avoid impacts linked to mining and transformation of raw coal, to natural gas consumption used (reactivation represents $40 \%$ of the gas consumption needed for the AC production), to toxicity risk (by 25\%) and to $\mathrm{CO}_{2}$ emissions (by almost $90 \%$ ) (Bayer et al., 2005). The implementation of a tertiary treatment is generally effective in reducing the residual toxicity of an effluent if the potential generation of by-products generated by oxidation processes (ex. ozonation) is controlled. However, the tertiary treatment requires additional consumption (chemicals, electricity, construction materials) which may affect the overall environmental impact. This is the conclusion reached by Rahman et al. (2018) for the treatment of emerging pollutants leaving urban wastewater treatment plants. Membrane filtration is the most impacting process due to the high energy consumption implemented unlike reactivated carbon filtration. In the future, an optimization of tertiary treatments is necessary to reduce their environmental impact and in particular their energy consumption (Margot, 2014).

\subsection{Performances of the tertiary treatments}


A comparison of the different processes studied is complex because the mechanisms for removing pollutants are very different. Membrane filtration and adsorption are separative processes while oxidation processes are destructive processes. Indeed, pollutants retained by RO or GAC are effectively eliminated from the treated water while the oxidation processes generally produce oxidation by-products leading to potential incomplete mineralization of pollutants. Moreover, performances are dependent on the wastewater quality (salinity, type and pollutant concentrations), the technology used and the operation conditions (type of membrane, pressure applied, nature of the activated carbon, kinetics, etc.).

Despite these points of attention, a summary of process performances according to category of pollutants is proposed in Table 2.

Table 2. Yields of elimination of priority and emerging pollutants by oxidation, adsorption and membrane filtration processes (Compilation APESA, RECORD 2020) adapted from (Besnault et al., 2014; Ruel et al., 2011). 
Membrane filtration

(RO)

\begin{tabular}{|c|c|c|c|}
\hline Organometallics & $>90 \%(a)$ & $40-70 \%(a)$ & $<40 \%$ (a) \\
\hline \multirow[t]{2}{*}{ Beta blockers } & $>70 \%$ & $\begin{array}{l}>99 \% \text { at } 6 \text { months } \\
(\mathrm{k})\end{array}$ & \multirow{2}{*}{$>98 \%(\mathrm{k})$} \\
\hline & $\begin{array}{l}30-70 \% \text { for } \\
\text { oxyprenolol }^{(b)}\end{array}$ & $\begin{array}{l}30-70 \% \text { for timolol } \\
\text { and nadolol }(\mathrm{b})\end{array}$ & \\
\hline Antibiotic drugs & $>70 \%(b)$ & $>73 \%(k)$ & $>72 \%(k)$ \\
\hline $\begin{array}{l}\text { Other drugs (carbamazepine, } \\
\text { diazepam, diclofenac and } \\
\text { erythromycin) }\end{array}$ & $\begin{array}{l}>70 \% \text { (except } \\
\text { erythromycin) }\end{array}$ & $\begin{array}{l}>85 \% \text { at } 6 \text { months } \\
\text { (k) }\end{array}$ & $\begin{array}{l}>99 \% \\
\text { and } 75 \% \text { for diazepam }{ }^{(k)}\end{array}$ \\
\hline Surfactants / detergents & (a) & (a) & (a) \\
\hline \multirow[t]{3}{*}{ Polycyclic Aromatic Hydrocarbon } & $\begin{array}{l}59-72 \%(c) \\
50-91 \%(d)\end{array}$ & \multirow{3}{*}{$\begin{array}{l}\text { Partially absorbed } \\
\text { less and less } \\
\text { efficient }{ }^{(k)} \\
72 \% \\
\text { Benzo(a)pyrene, } \\
94 \% \text { fluorene }(\mathrm{g})\end{array}$} & \multirow[t]{3}{*}{$\begin{array}{l}>90 \% \text { for acenaphtylene, } \\
\text { acenaphtene and pyrene our partial } \\
\text { elimination }(k)\end{array}$} \\
\hline & $\begin{array}{l}80 \% \text { Naphtalene } \\
\text { (e) } \\
>90 \% \text { Acenaphtylene, } \\
\text { Phenanthrene, Pyrene } \\
\text { (f) }\end{array}$ & & \\
\hline & $\begin{array}{l}>90 \% \\
\text { Benzo(a)pyrene }(\mathrm{g})\end{array}$ & & \\
\hline \multirow[t]{2}{*}{ Perfluorinated compounds } & \multirow[t]{2}{*}{$>90-99 \%(m)(h)$} & $\begin{array}{l}64 \% \text { PFOS and } 45 \% \\
\text { PFOA (I) to }>90 \% \\
\text { (m) }\end{array}$ & $\begin{array}{l}<10 \% \text { for PFOA } \\
10-50 \% \text { for PFOS }(m)\end{array}$ \\
\hline & & $\begin{array}{l}>90 \% \text { PFOA et } \\
\text { PFOS }^{(n)}\end{array}$ & \\
\hline \multirow{2}{*}{$\begin{array}{l}\text { Pesticides } \\
\text { (Atrazine, diuron, simazine, } \\
\text { isoproturon) }\end{array}$} & $>70 \%$ Simazine and & \multirow[t]{2}{*}{$>85 \%(k)$} & \multirow[t]{2}{*}{$>55 \%$ except for diuron, $(91 \%)^{(k)}$} \\
\hline & $84-97 \%$ Atrazine ${ }^{(i)}$ & & \\
\hline \multirow{4}{*}{$\begin{array}{l}\text { Pesticides } \\
\text { (glyphosate, AMPA) }\end{array}$} & $<30 \%$ AMPA $^{(b)}$ & \multirow{2}{*}{$\begin{array}{l}\text { Elimination } \\
\text { occurred only for } 3 \\
\text { months }{ }^{(k)}\end{array}$} & $>70 \%$ glyphosate ${ }^{(b)}$, \\
\hline & > 70\% glyphosate ${ }^{(b)}$ & & $63 \%$ AMPA $^{(b)}$ \\
\hline & \multirow{2}{*}{$\begin{array}{l}>90 \% \text { glyphosate } \\
\text { and > 95\% AMPA }(j)\end{array}$} & Non reliable ${ }^{(j)}$ & \multirow{2}{*}{$\begin{array}{l}60-99 \% \text { glyphosate and } 25-95 \% \\
\text { AMPA }^{(j)}\end{array}$} \\
\hline & & $\begin{array}{l}\text { Low performance } \\
\text { (o) }\end{array}$ & \\
\hline Color reference for the & $<30 \%$ & $30-70 \%$ & $>70 \%$ \\
\hline
\end{tabular}

Granular activated Ozone carbon

$30-70 \%$ for timolol
$>99 \%$ at 6 months $\quad>98 \%{ }^{(k)}$
Other drugs (carbamazepine, diazepam, diclofenac and

Surfactants / detergents

Polycyclic Aromatic Hydrocarbon

performances
$72 \%$

Benzo(a)pyrene $94 \%$ fluorene $(\mathrm{g})$
PFOA (l) to $>90 \%$

(m)

$>90 \%$ PFOA et

PFOS ${ }^{(n)}$

$>70 \%$ Simazine and $\quad>85 \%{ }^{(k)}$

$>70 \%$

Reference used: (a) (Fono \& McDonald, 2008), (b) - (Ruel et al., 2011), (c) - (Smol et al., 2015), (d) - (Gong et al., 2017), (e) (Dupont, 2020), (f) - (Zhu, 2015), (g) - (Snyder et al., 2007), (h) - (Flores et al., 2013), (i) - (Brinkmann et al., 2016), (j) - (Jönsson et al., 2013), (k) - (Besnault et al., 2014), (I) - (Flores et al., 2013), (m) - (AWWA), (n) - (Cummings et al., 2015), (o) - (Lenntech).

Membrane filtration reach the better performances for the elimination of priority and emerging pollutants. Granular activated carbon is efficient on a large part of the pollutants studies but organometallics and some pesticides can't be eliminated. In the 
same way, ozonation is not o good option for organometallics and perfluorinated compounds but it can reach good performances on some pesticides, drugs and Polycyclic Aromatic Hydrocarbon.

Performances of ozonation and activated carbon were compared in the framework of the MicroPoll project and showed that ozonation followed by a sand filter and Powder Activated Carbon (PAC) is effective in removing the majority of micropollutants with similar average removal rates. Ozone is very effective for some types of pollutants while PAC (Powder Activated Carbon) acts on a wider range of substances (but with lower yields) (Margot et al., 2013). Ozone and PAC significantly reduce the effluent toxicity with comparable costs (PAC separated by sand filter) (Margot et al., 2013) or higher (ultrafiltration used for PAC recovery). Combination of ozone and activated carbon allow to avoid the risk of toxic oxidation by-product rejection, adsorbed by AC. This coupling is implemented on urban wastewater treatment plants in Switzerland (Grelot et al., 2017). The French project Ampère has shown that RO has very high micropollutants abatement performance. Molecules hardly eliminated by activated carbon and ozonation were retained (Ruel et al., 2011).

\subsection{Comparison of the processes}

The three processes studied have specific characteristics with their own performances and degradation or separation efficiency. A comparison of the tertiary processes is proposed in Table $\mathbf{3}$ considering the main criteria that impact the choice of the treatment.

Table 3. Comparison of the main tertiary treatments: ozonation, membrane filtration and activated carbon. TSS (Total suspended solids). 


\begin{tabular}{|c|c|c|c|}
\hline & Ozonation & Membrane filtration NF/RO & Activated Carbon \\
\hline \multirow[t]{2}{*}{ Maturity } & $\begin{array}{l}\text { Standard process for the } \\
\text { micropollutant treatment }\end{array}$ & $\begin{array}{l}\text { Poorly used for micropollutant } \\
\text { treatments, }\end{array}$ & $\begin{array}{l}\text { Standard process for the } \\
\text { micropollutant treatment }\end{array}$ \\
\hline & & suitable for water reuse & \\
\hline \multirow[t]{2}{*}{ Performance } & Very high & Very high & Effective \\
\hline & & & $\begin{array}{l}\text { (depending on } \mathrm{AC} \text { and } \\
\text { regeneration frequency) }\end{array}$ \\
\hline $\begin{array}{l}\text { Pretreatment } \\
\text { need }\end{array}$ & $\begin{array}{l}\text { Elimination of } \\
\text { biodegradable COD and } \\
\text { TSS }\end{array}$ & Filtration of TSS & $\begin{array}{l}\text { Elimination of biodegradable } \\
\text { COD and TSS }(<10 \mathrm{mg} / \mathrm{L})\end{array}$ \\
\hline Chemicals & Oxygen & $\begin{array}{l}\text { Scale inhibitor and soda (for } \\
\text { membrane cleaning) }\end{array}$ & None \\
\hline $\begin{array}{l}\text { Electrical } \\
\text { consumption }\end{array}$ & High & High & $\begin{array}{l}\text { Low (except for reactivation } \\
\text { - high) }\end{array}$ \\
\hline $\begin{array}{l}\text { Staff } \\
\text { qualification }\end{array}$ & Medium & High & Low \\
\hline Implementation & Needs safety equipment & Available in modules & Easy. Possibility of renting. \\
\hline \multirow{2}{*}{$\begin{array}{l}\text { Environnemental } \\
\text { impact }\end{array}$} & Intermediate & High. & Low \\
\hline & $\begin{array}{l}\text { potential toxicity } \\
\text { (degradation by-products) }\end{array}$ & $\begin{array}{l}\text { (coupling transport and treatment of } \\
\text { retentate, energy and water recovery) }\end{array}$ & $\begin{array}{l}\text { (Transport for the treatment } \\
\text { of spent GAC) }\end{array}$ \\
\hline \multirow[t]{5}{*}{ Advantages } & Strong oxidizing power & Very high performance & \multirow{4}{*}{$\begin{array}{l}\text { Ease of implementation and } \\
\text { management } \\
\text { modular } \\
\text { Low investment cost, rental } \\
\text { possibility }\end{array}$} \\
\hline & Effective for a wide & \multirow{3}{*}{$\begin{array}{l}\text { Salt removal } \\
\text { Possibility to reuse treated water }\end{array}$} & \\
\hline & Numerous feedbacks & & \\
\hline & & & \\
\hline & & & Numerous feedbacks \\
\hline \multirow[t]{4}{*}{ Limits } & High costs & $\begin{array}{l}\text { Non-destructive process }(10-30 \% \text { of } \\
\text { retentate to be eliminated) }\end{array}$ & $\begin{array}{l}\text { Periodic replacement } \\
\text { (elimination/reactivation) }\end{array}$ \\
\hline & $\begin{array}{l}\text { Generation of potentially } \\
\text { toxic oxidation by-products }\end{array}$ & Energy consumption & Risk of clogging \\
\hline & Ineffective on certain & Risk of fouling & Drastic performance \\
\hline & & Maintenance : cleaning & \\
\hline
\end{tabular}

To complete this first comparison, a multi-criteria approach is proposed to assess and compare the processes. Adapted from the methodology reported by Fast et al. (2017), this approach is based on the evaluation of process performance according to technical, environmental and economic criteria. Different key points have been defined with a rating base proposed allowing the reproducibility of this approach presented. The rating is carried out by applying a score ranging from 1 to 5 . The highest scores correspond to the best performances. Technical and environmental criteria rating are based on the data listed previously and regrouped in topics detailed by method in Supplementary material. This ranking is not an absolute indication indeed, all the criteria were considered without weighting according to the method used by Fast et al. (2017). This could be discussed, in the same way other criteria could have been considered. The scoring results obtained are shown in Table 4 and Fig. 2. 
Table 4. Results of the scoring of the processes (APESA, RECORD 2020).

\begin{tabular}{|c|c|c|c|c|c|c|}
\hline Criteria & Quotation basis & $\begin{array}{l}\text { Reverse } \\
\text { Osmosis }\end{array}$ & $\begin{array}{l}\text { Reverse } \\
\text { Osmosis with } \\
\text { water reuse }\end{array}$ & $\begin{array}{l}\text { GAC } \\
\text { Reactivation }\end{array}$ & $\begin{array}{l}\text { GAC } \\
\text { Elimination }\end{array}$ & Ozonation \\
\hline $\begin{array}{l}\text { Technical } \\
\text { criteria }\end{array}$ & & 3.6 & 3.6 & 4.4 & 4.4 & 4.2 \\
\hline $\begin{array}{l}\text { Level of } \\
\text { development }\end{array}$ & Nbr of industrial units & 4.0 & 4.0 & 5.0 & 5.0 & 5.0 \\
\hline $\begin{array}{l}\text { Technical } \\
\text { reliability }\end{array}$ & Material reliability & 3.0 & 3.0 & 4.0 & 4.0 & 4.0 \\
\hline Performances & $\begin{array}{l}\text { High efficiency and } \\
\text { constant over time }\end{array}$ & 5.0 & 5.0 & 4.0 & 4.0 & 4.0 \\
\hline $\begin{array}{l}\text { Flexibility / } \\
\text { adaptability }\end{array}$ & $\begin{array}{l}\text { Variation of flow and load } \\
\text { to be treated }\end{array}$ & 3.0 & 3.0 & 4.0 & 4.0 & 4.0 \\
\hline $\begin{array}{l}\text { Operational } \\
\text { Complexity }\end{array}$ & $\begin{array}{l}\text { Nbr of processes and their } \\
\text { innovative aspect }\end{array}$ & 3.0 & 3.0 & 5.0 & 5.0 & 4.0 \\
\hline $\begin{array}{l}\text { Environmental } \\
\text { impact }\end{array}$ & & 3.5 & 3.5 & 4.3 & 3.8 & 4.0 \\
\hline $\begin{array}{l}\text { Energy } \\
\text { consumption }\end{array}$ & & 3.0 & 3.0 & 5.0 & 5.0 & 3.0 \\
\hline $\begin{array}{l}\text { Toxicity of the } \\
\text { water treated }\end{array}$ & $\begin{array}{l}\text { Generation of oxidation by- } \\
\text { products or chemical } \\
\text { releases }\end{array}$ & 5.0 & 5.0 & 4.0 & 4.0 & 4.0 \\
\hline $\begin{array}{l}\text { Wastes } \\
\text { (production } \\
\text { and transport) }\end{array}$ & & 2.0 & 2.0 & 4.0 & 2.0 & 5.0 \\
\hline $\begin{array}{l}\text { Possibility of } \\
\text { recycling water }\end{array}$ & & 4.0 & 5.0 & 4.0 & 4.0 & 4.0 \\
\hline $\begin{array}{l}\text { Economic } \\
\text { criteria }\end{array}$ & & 2.8 & 3.3 & 4.3 & 2.9 & 3.2 \\
\hline $\begin{array}{l}\text { O\&M cost }\left(€ \mathrm{~m}^{-}\right. \\
3)\end{array}$ & & 1.7 & 2.8 & 3.6 & 0.9 & 2.2 \\
\hline $\begin{array}{l}\text { Capital cost }(€ \\
\left.\mathrm{m}^{-3}\right)\end{array}$ & Amortized annual & 3.8 & 3.8 & 4.9 & 4.9 & 4.2 \\
\hline
\end{tabular}

Average Score 3.3

First, all the process analyzed have a ranking between 3.3 and 4.3 showing globally good performances. Activated carbon adsorption obtains the best results when reactivation is applied on the spent carbon. On the contrary the RO presents the lower score due to the complexity of operation with the risk of fouling and scaling. Moreover the production of wastes (retentate) is a major drawback that increases the O\&M cost. On contrary the possibility of reusing water is a great advantage that can lead to choose this solution. It can solve problems of availability of freshwater or impossibility to discharge wastewater.

The results of this ranking have to be considered only for the scenarios studied. Other results could have been found for other wastewaters with lower flowrate or organic concentration. The choice of the process will be made according to the effluent to be treated (flow rate, load, nature of pollutants) and the local context. Moreover, the quotation applied may differ depending on the person carrying out this quotation with a subjective part on the weighting parameters for example. However, the proposed 


\subsection{Strategy defined for the estimation of the tertiary treatment best option}

These different processes can be complementary and must be chosen according to the effluent nature to be treated, its flow rate and the treatment objectives to be achieved.

Biological processes not evaluated in this study have the lowest costs and are preferred when pollution is biodegradable. They are widely used for the treatment of urban and industrial wastewater. Partial oxidation can be necessary to increase the biodegradability of an effluent before a bio-treatment in presence of recalcitrant pollutants. This option is generally less expensive than total oxidation when the residual COD is greater than $350 \mathrm{mg} / \mathrm{L}$. Membrane filtration will be useful for water reuse projects and/or when the effluent is refractory to oxidation. Adsorption will be implemented for the treatment of low flows of organics or pollutants refractory to oxidation. The adsorption can also make it possible to eliminate oxidation by-products. A simplified decision tree has been designed to choose the best option according to the effluent composition for the treatment of organic pollutants from industrial or urban effluents (Fig. 3).

As described previously, the choice of the best wastewater treatment scheme will be a combination of processes on a case-bycase basis depending on the effluent to be treated and the treatment objectives. However, by coupling this decision tree and the ranking methodology presented, an impartial and customizable choice can be made.

\section{Conclusion}

This study aims at establishing the better course for effluent remediation with dissolved organic matter load with refractory compounds. Different wastewater treatment strategies can be studied depending on the nature of the wastewater, the water flow rate and the treatment objectives.

A methodology was designed for the rating of tertiary processes to choose the best strategy on environmental, technical and economic criteria.

From this tool, we have compared the most effective tertiary treatments for recalcitrant COD. The best result was obtained by the activated carbon when reactivation is applied on the spent carbon which allowed to reduce the 0\&M cost and the environmental footprint. On the contrary the reverse osmosis presents the lower score due to the complexity of operation and the production of retentate which is a major drawback that increases the 0\&M cost and the environmental footprint. However, the possibility of reusing water is a great advantage that can lead to reduce the $0 \& \mathrm{M}$ cost and solve problems of availability of freshwater or impossibility of discharge of wastewater. Ozonation obtained intermediate result. It is very effective but costs can be high when the organics concentration of the wastewater is high. Despite their performance, oxidation processes generally do not completely mineralize organic matter and the formation of potentially toxic oxidation by-products can be problematic. A post-treatment (sand filter, adsorption on activated carbon or bio-treatment) may be necessary to eliminate these by-products. Generally, ozonation is very effective, however, it can't oxidize all the molecules. Advanced Oxidation Processes (AOPS) could be a solution in this case. They are able to generate non-selective and highly reactive hydroxyl radicals, which are effective on the majority of organic compounds. They can be chemical, photochemical, catalytic, electrochemical, sonochemical and physical. The AOPs will be reserved for the treatment of the most problematic effluents with difficult compounds. Generally, adsorption on activated carbon and membrane filtration (NF/RO) can deal with effluents refractory to oxidation processes. When the refractory COD concentrations are high, other methods will be more suitable. Evapo-concentration or thermal oxidation processes (wet oxidation, supercritical oxidation) can manage effluent concentrations up to $100 \mathrm{~g} \mathrm{~L}^{-1}$ of COD, above these concentrations incineration is generally the only treatment solution. 
A decision tree was designed to summarize the results of this study and facilitate the choice of the processes to implement for the treatment of organic (non-particulate) pollutants in low concentration. The choice of the treatment process or the combination of processes will be made on a case-by-case basis depending on the effluent to be treated and the treatment objectives.

\section{Declarations}

\section{Acknowledgements}

Authors are grateful to the French Industry-University Cooperative Research Network on environment and Waste (RECORD www.record-net.org) for its contribution to the funding of this work and for providing industrial orientations and scientific supervision to the research.

Funding - This project was fund by the French Industry-University Cooperative Research Network on environment and Waste (RECORD).

Conflicts of interest/Competing interests - Authors do not known on any conflicts of interest or competing interests.

Ethics approval - No experimentations have been performed in this publication.

Consent to participate \& Consent for publication - All of the authors have been consulted before submission of this paper.

Availability of data and material - A supplementary material is available, all the calculations performed are explained and any supplementary questions can be address at email address given.

Code availability - No software were used in this publication.

Authors' contributions - Peyrelasse performed the calculations and write the publication; Lallement, \& Jacob review the publication.

\section{References}

1. /105/EC (2008) DIRECTIVE 2008/105/EC OF THE EUROPEAN PARLIAMENT AND OF THE COUNCIL of 16 December 2008 on environmental quality standards in the field of water policy, amending and subsequently

2. repealing Council Directives 82/176/EEC, 83/513/EEC, 84/156/EEC, 84/491/EEC, 86/280/EEC and amending Directive 2000/60/EC of the European Parliament and of the Council, (Ed.) O.J.o.t.E. Union

3. /39/EU (2013) DIRECTIVE 2013/39/EU OF THE EUROPEAN PARLIAMENT AND OF THE COUNCIL of 12 August 2013 amending Directives 2000/60/EC and 2008/105/EC as regards priority substances in the field of water policy, (Ed.) O.J.o.t.E. Union

4. Andrade LH, Aguiar AO, Pires WL, Miranda GA, Teixeira LPT, Almeida GCC, Amaral MCS (2017) Nanofiltration and Reverse Osmosis Applied to Gold Mining Effluent Treatment and Reuse. Braz J Chem Eng 34(1):93-107

5. Andrade LH, Mendes FDS, Espindola JC, Amaral MCS (2015) Reuse of Dairy Wastewater Treated by Membrane Bioreactor and Nanofiltration: Technical and Economic Feasibility. Braz J Chem Eng 32(3):735-747

6. AWWA. Perfluorinated compounds: Treatment and removal

7. Baalbaki Z, Sultana T, Metcalfe C, Yargeau V (2017) Estimating removals of contaminants of emerging concern from wastewater treatment plants: The critical role of wastewater hydrodynamics. Chemosphere 178:439-448

8. Baig S, Mouchet P (2017) Oxydation et réduction appliquées au traitement de l'eau - Ozone - Autres oxydants - Oxydation avancée - Réducteurs. Techniques de I'Ingénieur, W2702 V1

9. Bayer P, Heuer E, Karl U, Finkel M (2005) Economical and ecological comparison of granular activated carbon (GAC) adsorber refill strategies. Water Res 39(9):1719-1728

Page $14 / 19$ 
10. besnault S, Martin-Ruel S, Baig S, Heiniger B, Esperanza M, Budzinski H, Miege C, Le Menach K, Dherret L, Roussel-Galle A, Coquery M (2015) Evaluation technique, économique et environnementale de procédés de traitement complémentaire avancés pour l'élimination des micropolluants. TSM 3:67-83

11. Besnault S, Martin S, Baig S, Budzinski H, Le Menach K, Esperanza M, Noyon N, Gogot C, Miège C, Dherret L, Roussel-Galle A, Coquery M (2014) Réduction des micropolluants par les traitements complémentaires: procédés d'oxydation avancée, adsorption sur charbon actif.

12. Bick A, Gillerman L, Manor Y, Oron G (2012) Economic Assessment of an Integrated Membrane System for Secondary Effluent Polishing for Unrestricted Reuse. Water 4(1):219-236

13. Brinkmann T, Santonja GG, Yükseler H, Roudier S, Delgado Sancho L (2016) Best Available Techniques (BAT) Reference Document for Common Waste Water and Waste Gas Treatment/Management Systems in the Chemical Sector EUR 28112 EN

14. Bui XT, Vo TP, Ngo HH, Guo WS, Nguyen TT (2016) Multicriteria assessment of advanced treatment technologies for micropollutants removal at large-scale applications. Sci Total Environ 563-564:1050-1067

15. Burn S, Hoang M, Zarzo D, Olewniak F, Campos E, Bolto B, Barron O (2015) Desalination techniques - A review of the opportunities for desalination in agriculture. Desalination 364:2-16

16. Choubert JM (2018) Élimination des micropolluants présents dans les rejets de STEU Quels procédés ? Quelles conditions de fonctionnement?

17. Chronopoulos G, Cakmak G-E, Tempany P, Klein G, Brinkmann T, Zerger B, Roudier S (2019) Best Available Techniques (BAT) Reference Document on Surface Treatment Using. Organic Solvents including Preservation of Wood and Wood Products with Chemicals

18. Coquery M, Eusèbe M, Ribeiro L, Choubert JM, Miège $C$ (2008) Removal efficiency of pharmaceuticals and personal care products with varying wastewater treatment processes and operating conditions - conception of a database and first results. Water Sci Technol 57(1):49-56

19. Cummings L, Matarazzo A, Nelson N, Sickels F, Storms CT (2015) Recommendation on Perfluorinated Compound Treatment Options for Drinking Water

20. de Franceschi L (2018) Ozone, O3 Plus AOP: an optimized treatment line for COD \& TOC removal. Wahua, from lab tests to full scale plant. In: Ozone and advanced oxidation solutions for emerging pollutants of concern to the water and the environment. International Ozone Association, Lausanne

21. Du B, Price AE, Scott WC, Kristofco LA, Ramirez AJ, Chambliss CK, Yelderman JC, Brooks BW (2014) Comparison of contaminants of emerging concern removal, discharge, and water quality hazards among centralized and on-site wastewater treatment system effluents receiving common wastewater influent. Science of The Total Environment 466467:976-984

22. Dupont (2020) Estimated Percent Rejection of Various Solutes by FilmTec ${ }^{T M}$ Membranes. Form No. 45-D01926-en, Rev. 2 ed. in: Tech Fact, (Ed.) Dupont

23. European commission (2000) Directive 2000/60/EC of the european parliament and of the council of 23 October 2000 establishing a framework for Community action in the field of water policy

24. European Commission (2010) Directive 2010/75/EU of the European Parliament and of the Council of 24 November 2010 on industrial emissions (integrated pollution prevention and control)

25. Fast SA, Gude VG, Truax DD, Martin J, Magbanua BS (2017) A Critical Evaluation of Advanced Oxidation Processes for Emerging Contaminants Removal. Environmental Processes 4(1):283-302

26. Flores C, Ventura F, Martin-Alonso J, Caixach J (2013) Occurrence of perfluorooctane sulfonate (PFOS) and perfluorooctanoate (PFOA) in N.E. Spanish surface waters and their removal in a drinking water treatment plant that combines conventional and advanced treatments in parallel lines. Sci Total Environ, 461-462, 618 - 26

27. Fono L, McDonald S (2008) Emerging compounds: A concern for Water and wastewater utilities. Journal AWWA (American Water Works Association) 100(11):50-57 
28. G.Melin (Ed.). 1999. Treatment Technologies for Removal ofMethyl TertiaryButyl Ether (MTBE) from Drinking Water: Air Stripping, Advanced Oxidation Processes, Granular Activated Carbon and Synthetic Resin Sorbents. Center for Groundwater Restoration and Protection, NationalWater Research Institute

29. Gong C, Huang H, Qian Y, Zhang Z, Wu H (2017) Integrated electrocoagulation and membrane filtration for PAH removal from realistic industrial wastewater: effectiveness and mechanisms. RSC Advances 7(83):52366-52374

30. Grelot J, Wunderlin P, Lausanne m (2017) Vue d'ensemble et choix des techniques de traitement Elimination des micropolluants - Mise en œuvre de la législation sur la protection des eaux: le bilan, un an après Lausanne

31. Guo C, Chang H, Liu B, He Q, Xiong B, Kumar M, Zydney AL (2018) A combined ultrafiltration-reverse osmosis process for external reuse of Weiyuan shale gas flowback and produced water. Environmental Science: Water Research Technology 4(7):942-955

32. Guo T, Englehardt J, Wu T (2014) Review of cost versus scale: water and wastewater treatment and reuse processes. Water Sci Technol 69(2):223-234

33. Gusmaroli L, Mendoza E, Petrovic M, Buttiglieri G (2020) How do WWTPs operational parameters affect the removal rates of EU Watch list compounds? Science of The Total Environment 714:136773

34. Najjar HE, Touffet N, Deborde A, Journel M, Vel Leitner RKarpel, N (2014) Kinetics of paracetamol oxidation by ozone and hydroxyl radicals, formation of transformation products and toxicity. Sep Purif Technol 136:137-143

35. Hansen SP, Gumerman RC, Culp RL (1979) Estimating water treatment costs. Volume 3. Cost Curves Applicable to 2,500 gpd to 1 mgd Treatment Plants

36. IRH (2010) Etude sur les coûts de réduction des rejets de substances toxiques

37. Jönsson J, Camm R, Hall T (2013) Removal and degradation of glyphosate in water treatment: a review. Journal of Water Supply: Research Technology-Aqua 62(7):395-408

38. JORF (2017) Arrêté du 24 août 2017 modifant dans une série d’arrêtés ministériels les dispositions relatives aux rejets de substances dangereuses dans l'eau en provenance des installations classées pour la protection de l'environnement

39. (Ed.) M.d.I.t.é.e. solidaire. JORF n0234 du 6 octobre 2017

40. Koroneos C, Dompros A, Roumbas G (2007) Renewable energy driven desalination systems modelling. J Clean Prod 15(5):449-464

41. Landry Carter M (2017) Le traitement d'eaux de détoxication de bois traité par procédés d'oxydation simple et avancée Vol. Mémoire de maïtrise, Université de Sherbrooke

42. Lenntech. Adsorption / Active Carbon

43. Li Y, Zhang S, Zhang W, Xiong W, Ye Q, Hou X, Wang C, Wang P (2019) Life cycle assessment of advanced wastewater treatment processes: Involving 126 pharmaceuticals and personal care products in life cycle inventory. J Environ Manage 238:442-450

44. Mahamuni NN, Adewuyi YG (2010) Advanced oxidation processes (AOPs) involving ultrasound for waste water treatment: a review with emphasis on cost estimation. Ultrason Sonochem 17(6):990-1003

45. Margot J (2014) Traitement des micropolluants dans les eaux usées: bases théoriques et état de la recherche. In: Micropolluants dans les eaux usées. Ecole Polytechnique Fédérale de Lausanne, Lausanne

46. Margot J, Kienle C, Magnet A, Weil M, Rossi L, de Alencastro LF, Abegglen C, Thonney D, Chevre N, Scharer M, Barry DA (2013) Treatment of micropollutants in municipal wastewater: ozone or powdered activated carbon? Sci Total Environ, 461-462, $480-98$

47. Margot J, Magnet A, Thonney D, Chèvre N, de Alencastro F, Rossi L (2011) Traitement des micropolluants dans les eaux usées - Rapport final sur les essais pilotes à la. STEP de Vidy (Lausanne).

48. Mendret J, Azais A, Favier T, Brosillon S (2019) Urban wastewater reuse using a coupling between nanofiltration and ozonation: Techno-economic assessment. Chem Eng Res Des 145:19-28

49. Metz F, Ingold K (2014) Sustainable wastewater management: is it possible to regulate micropollution in the future by learning from the past? A policy analysis. Sustainability 6:1992-2012

Page 16/19 
50. Mundy B, Kuhnel B, Hunter G, Jarnis R, Funk D, Walker S, Burns N, Drago J, Nezgod W, Huang J, Rakness K, Jasim S, Joost R, Kim R, Muri J, Nattress J, Oneby M, Sosebee A, Thompson C, Walsh M, Schulz C (2018) A Review of Ozone Systems Costs for Municipal Applications. Report by the Municipal Committee - IOA Pan American Group. Ozone: Science Engineering 40(4):266-274

51. Nijdam D, Blom J, Boere JA (1999) Environmental Life Cycle Assessment (LCA) of two advanced wastewater treatment techniques. 120, 763-775

52. Norman (2018) Network of reference laboratories, research centres and related organisations for monitoring of emerging environmental substances. in: Glossary of Terms, Vol. 2018, Norman

53. Norman (2019) NORMAN List of Emerging Substances, Network of reference laboratories. research centres and related organisations for monitoring of emerging environmental substances

54. Pedro-Monzonis M, Solera A, Ferrer J, Andreu J, Estrela T (2016) Water accounting for stressed river basins based on water resources management models. Sci Total Environ 565:181-190

55. Pinasseau A, Zerger B, Roth J, Canova M, Roudier S (2018) Best Available Techniques (BAT) Reference Document for Waste treatment Industrial Emissions Directive 2010/75/EU. Integrated Pollution Prevention and Control)

56. Plumlee MH, Stanford BD, Debroux J-F, Hopkins DC, Snyder SA (2014) Costs of Advanced Treatment in Water Reclamation. Ozone: Science Engineering 36(5):485-495

57. Rahman SM, Eckelman MJ, Onnis-Hayden A, Gu AZ (2018) Comparative Life Cycle Assessment of Advanced Wastewater Treatment Processes for Removal of Chemicals of Emerging Concern. Environ Sci Technol 52(19):11346-11358

58. RECORD (2006) Association de bioprocédés à d'autres procédés dans le traitement ex situ de déchets et sols pollués

59. Ruel SM, Choubert JM, Esperanza M, Miège C, Navalón Madrigal P, Budzinski H, Le Ménach K, Lazarova V, Coquery M (2011) On-site evaluation of the removal of 100 micro-pollutants through advanced wastewater treatment processes for reuse applications. Water Sci Technol 63(11):2486-2497

60. Shouman ER, Sorour M, Abulnour A (2015) Economics of Renewable Energy for Water Desalination in Developing Countries. Int J Econ Manag Sci

61. Smol M, Włodarczyk-Makuła M, Mielczarek K, Bohdziewicz J, Włóka D (2015) The Use of Reverse Osmosis in the Removal of PAHs from Municipal Landfill Leachate. Polycyclic Aromat Compd 36:20-39

62. Snyder SA, Wert EC, Hongxia (Dawn), L, Paul W, Yeomin Y (2007) Removal of EDCs and Pharmaceuticals in Drinking and Reuse Treatment Processes. American Waterworks Association Research Foundation

63. Truc A (2007) Traitements tertiaires des effluents industriels. in: Traitements tertiaires des effluents industriels, (Ed.) T.d. l'ingénieur, Vol. g1310

64. Wahlberg C, Björlenius B, Paxéus N (2010) Läkemedelsrester i Stockholms vattenmiljö - Förekomst, förebyggande åtgärder och rening av avloppsvatten (Pharmaceuticals - Presence and effects in the aquatic environment, preventive measures and possible treatment methods).. Stockholm Water Company, Stockholm

65. Wu QY, Zhou YT, Li W, Zhang X, Du Y, Hu HY (2019) Underestimated risk from ozonation of wastewater containing bromide: Both organic byproducts and bromate contributed to the toxicity increase. Water Res 162:43-52

66. Xylem (2017) Pulp \& Paper Mill Enhancements for Green Productivity Benefits. IPPTA AGM, Chennai

67. Zhu L (2015) Rejection of Organic Micropollutants by Clean and Fouled Nanofiltration Membranes. Journal of Chemistry, $2015,1-9$

\section{Figures}




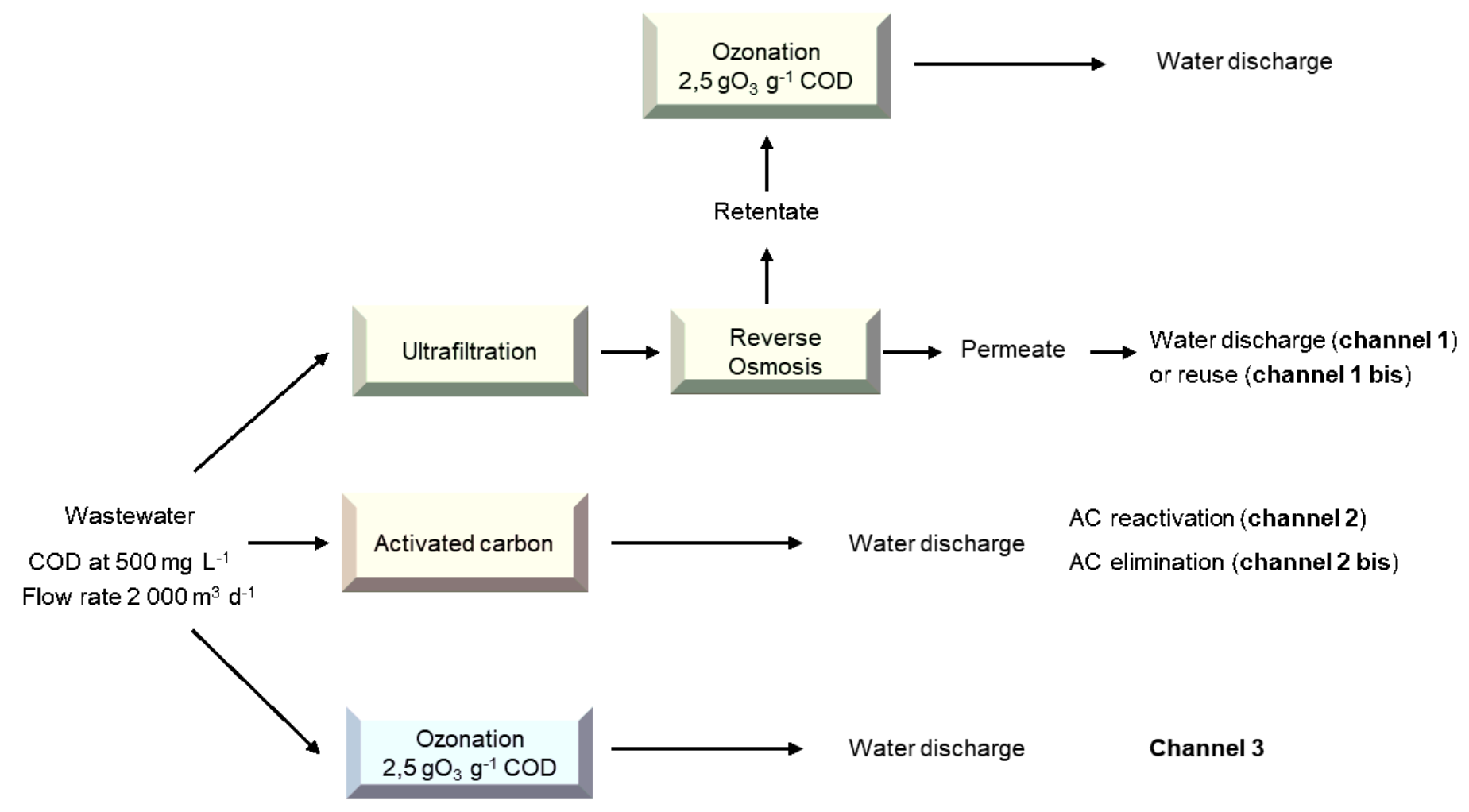

\section{Figure 1}

Wastewater treatment scenarios used for the cost evaluation. The COD concentration of the water discharge is less than $50 \mathrm{mg}$ L-1.

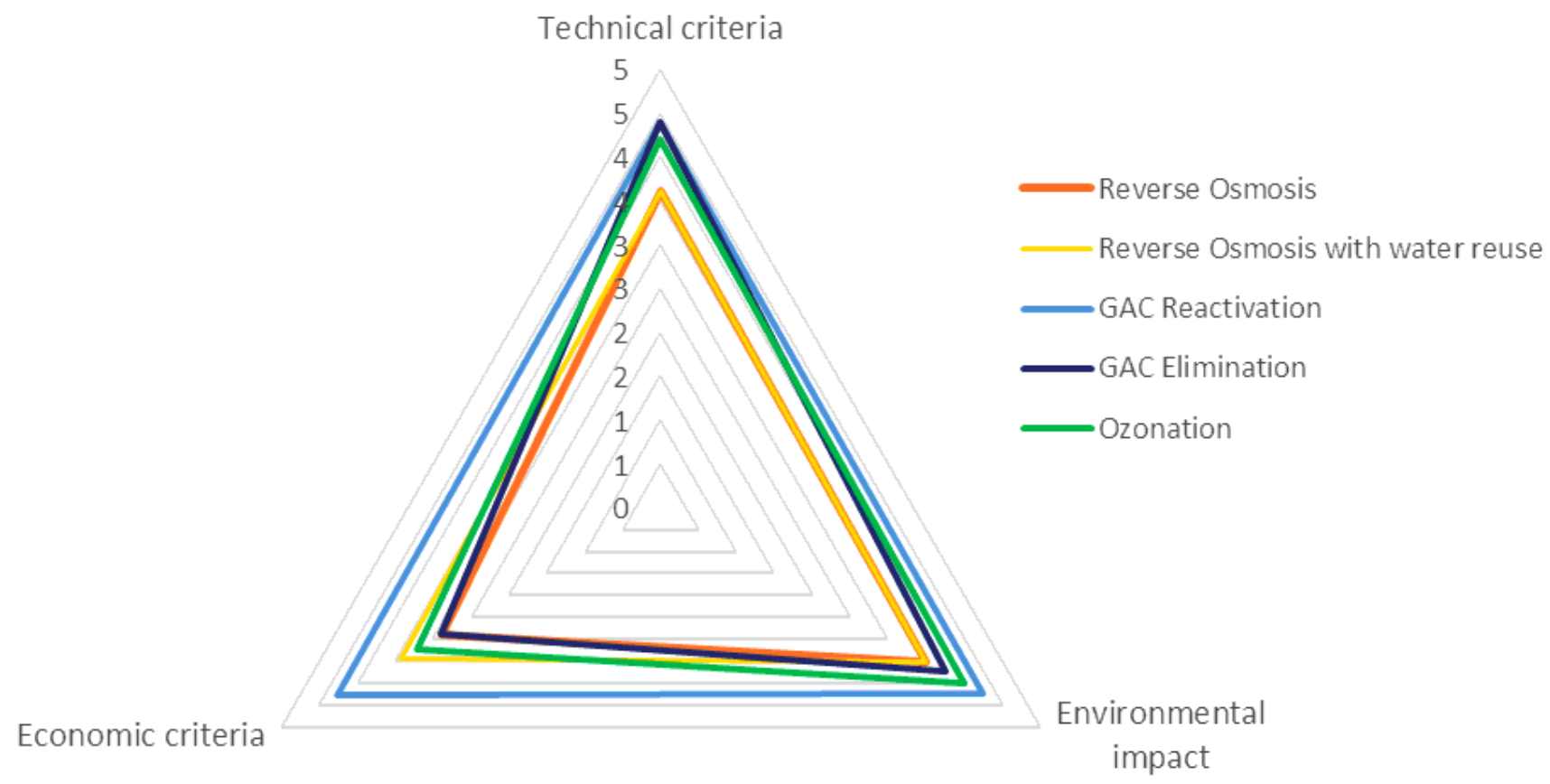

Figure 2 
Comparison of ranking of the three technologies (ozonation, RO with or without water reuse and GAC with reactivation or elimination) according technical, economic and environmental criteria.

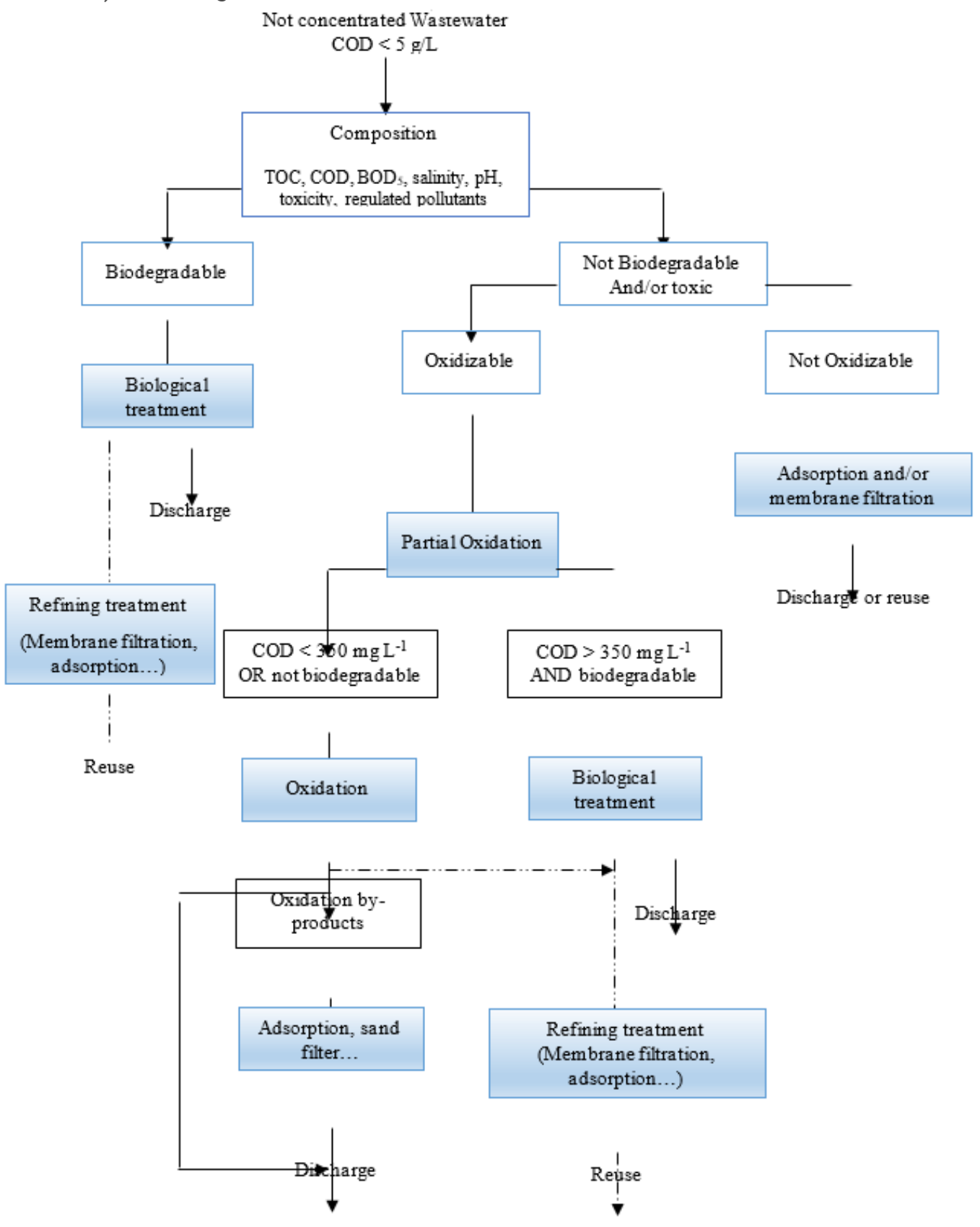

\section{Figure 3}

Decision tree designed for the treatment of organic (non-particulate) pollutants in low concentration.

\section{Supplementary Files}

This is a list of supplementary files associated with this preprint. Click to download.

- Peyrelasseal.Record2021Supplementarymaterial.docx 